Doi: 10.30868/ad.v4i02.715

\title{
COMPARATIVE ANALYSIS OF THE THOUGHTS OF M. UMER CHAPRA AND M. ABDUL MANNAN ABOUT THE CONCEPT OF RIBA AND BANKING
}

\section{ANALISIS KOMPARATIF PEMIKIRAN M. UMER CHAPRA DAN M. ABDUL MANNAN TENTANG KONSEP RIBA DAN PERBANKAN}

\author{
Muhammad Naufal Lazuardi ${ }^{1}$, Purbayu Budi Santosa ${ }^{2}$ \\ ${ }^{1,2}$ Fakultas Ekonomika dan Bisnis Universitas Diponegoro \\ muh.naufallazuardi@gmail.com \\ purbayubs@gmail.com
}

\begin{abstract}
The existence of Islamic economics as an economic concept that continues to grow and develop, especially in the contemporary era, needs to be addressed with a wise attitude, one of which is by examining various perspectives, including the thought of leaders about the concept of riba and banking, so various parties must own that knowledge about the concept of riba and banking. This study uses qualitative methods with the type of library research with a comparative approach. This literature research explains and compares the thoughts of two contemporary Islamic economic figures, namely M. Umer Chapra and M. Abdul Mannan. The data analysis technique used is a content analysis and comparative. The data is obtained by reviewing books, scientific works in printed or electronic form, and all other written material. The author attempts to describe the two objects of research, analyze them, and then compare the two objects' results by combining several content dimensions from these two objects. The author uses the intersection union tool to compare several dimensions from the two figures' thoughts regarding the concept of riba and banking. The study results show that M. Umer Chapra and M. Abdul Mannan's thoughts on the concept of riba and banking are classified into the same or similar dimension. The second thought of Islamic economic figures is related to one another. Both figures agreed to integrate Islamic values derived from the Qur'an and Hadits into every economic activity.
\end{abstract}

Keyword: concept of riba and banking, thought of m. umer chapra, thought of m. abdul mannan

\footnotetext{
ABSTRAK

Keberadaan ekonomi Islam sebagai salah satu konsep ekonomi yang terus tumbuh dan berkembang khususnya di era kontemporer ini perlu disikapi dengan sikap yang arif dan bijak, salah satunya dengan menelaah berbagai sudut pandang, termasuk pemikiran para tokoh mengenai konsep riba dan perbankan, sehingga pengetahuan mengenai konsep riba dan perbankan secara mendasar harus dimiliki oleh berbagai pihak. Penelitian ini menggunakan metode kualitatif dengan jenis penelitian kepustakaan dengan pendekatan komparatif. Penelitian kepustakaan ini menjelaskan dan membandingkan pemikiran dua tokoh ekonomi Islam kontemporer yaitu M. Umer Chapra dan M. Abdul Mannan. Teknik analisis data yang digunakan yaitu analisis isi (content analysis) dan komparatif. Data dapat diperoleh dengan mengkaji buku, karya ilmiah dalam bentuk cetak ataupun elektronik, dan sebuah bahan tertulis lainnya. Penulis berupaya menggambarkan kedua objek penelitian dan menganalisisnya lalu membandingkan hasil dari kedua objek tersebut dengan menggabungkan beberapa dimensi isi
} 
dari kedua objek ini. Penulis menggunakan alat interseksi union untuk membandingkan beberapa dimensi dari pemikiran kedua tokoh mengenai konsep riba dan perbankan. Hasil penelitian menunjukkan pemikiran M. Umer Chapra dan M. Abdul Mannan mengenai konsep riba dan perbankan digolongkan ke dalam dimensi yang sama atau sejenis. Pemikiran kedua tokoh ekonomi Islam ini berhubungan satu sama lain. Kedua tokoh sepakat untuk mengintegrasikan nilai-nilai Islam yang bersumber dari Al Qur'an dan Hadits ke dalam aktivitas ekonomi.

Kata Kunci: konsep riba dan perbankan, pemikiran m. umer chapra, pemikiran m. abdul mannan

\section{A. PENDAHULUAN}

Perkembangan pemikiran ekonomi Islam kian menggeliat terutama sejak lahirnya madzhab-madzhab ekonomi Islam, seperti Baqir Al-Sadr, mainstream, dan alternatif-kritis. Perkembangan tersebut tentu saja sangat menggembirakan karena akan semakin banyak masalah terutama di bidang ekonomi yang dapat dipecahkan oleh ajaran-ajaran Islam.

Islam memosisikan kegiatan ekonomi sebagai salah satu aspek penting untuk mendapatkan kebahagiaan (falah), sebab tujuan akhir kegiatan ekonomi Islam adalah sebagaimana tujuan syariat Islam itu sendiri (maqashid syariah), yaitu kebahagiaan di dunia dan di akhirat. Berdasarkan landasan tujuan akhir falah, motif ekonomi dalam Islam merupakan ibadah, maka kegiatan ekonominya harus dikontrol dan dituntun agar sejalan dengan ajaran Islam secara keseluruhan (kaffah).

Perkembangan pemikiran ekonomi Islam dapat dipahami bahwa ekonomi Islam pada dasarnya sudah dibahas dan dipraktikan dalam kehidupan sehari-hari, bahkan sejak zaman Rasulullah shalallahu 'alaihi wa sallam dan sahabat-sahabatnya. Akan tetapi, perkembangan ekonomi Islam terhenti, karena adanya dikotomi antara agama dan ilmu pengetahuan yang lahir akibat dogmatisasi yang terjadi pada masa kegelapan (taqlid), konsekuensinya ada ketidakpercayaan terhadap kesalahan yang muncul dalam bidang ekonomi. Selain itu, kuatnya dominasi ekonomi kapitalis dan sosialis buah dari politik imperialisme dan kolonialisme menjadikan ekonomi Islam makin tergerus dan mulai ditinggalkan.

Keadaan tersebut makin diperparah dengan diabaikannya kontribusi pemikiran ekonomi Islam tersebut oleh para pemikir ekonomi Barat. Hal ini dibuktikan dengan cara buku-buku teks ekonomi Barat yang hampir tidak pernah menyebutkan peranan kaum Muslimin. Para sejarawan Barat telah menulis sejarah ekonomi dengan asumsi bahwa periode antara Yunani dan Skolastik adalah steril dan tidak produktif (Karim, 2015).

Kurang lebih pada tahun 1930-an ekonomi Islam kembali bergeliat menancapkan eksistensinya sebagai salah satu bangunan ilmu yang kukuh dan mampu menjawab berbagai permasalahanpermasalahan ekonomi kontemporer. Jika dilihat dalam konteks wacana pemikiran ekonomi Islam kontemporer, maka akan didapatkan ada tiga madzhab besar yang sangat mempengaruhi teori-teori ekonomi Islam. Madzhab-madzhab ekonomi ini memiliki pandangan yang berbeda terhadap permasalahan ekonomi. Pemahaman berbeda ini dilatarbelakangi oleh metode yang dipakainya.

Perkembangan pemikiran mengenai ekonomi Islam memasuki babak baru pada tahun 1970-an, dan hal tersebut langsung berada ditingkat internasional. Perkembangan pemikiran ekonomi Islam 
ini dipengaruhi oleh beberapa faktor. Pertama, munculnya kekuatan baru ekonomi yang disebut petro dollar, hal ini dimaknai dengan dollar yang dihasilkan oleh industri perminyakan. Kedua, munculnya kesadaran tentang kebangkitan Islam pada abad ke-14 Hijriyah yang melanda dunia Islam pada tahun 1970-an. Ketiga, lahirnya generasi baru intelektual Muslim yang mendapatkan pendidikan modern, baik di Barat maupun di negaranegara Islam sendiri.

Seiring berjalannya waktu, kebutuhan hidup manusia semakin berkembang, hal tersebut menjadikan kegiatan ekonomi semakin bervariatif. Bersamaan dengan hal tersebut, mulai bermunculan lembagalembaga penunjang perekonomian, salah satunya adalah lembaga perbankan yang berfungsi untuk mengatur alur arus keuangan. Di dunia barat perkembangan keuangan dalam bentuk kelembagaan tumbuh subur dengan dibantu oleh sentuhan teknologi yang dapat mempermudah arus transaksi.

Ciri khas dari lembaga keuangan, khususnya yang terdapat dalam perbankan adalah penggunaan bunga pada sistem operasionalnya. Hadirnya perbankan dalam dunia Islam bukan merupakan hal yang asing, karena istilah perbankan sudah dikenal sejak masa pertengahan Islam (Fajar, 2009). Robert Rodkey dalam AlKaaf (2002) mengatakan bahwa bank deposit pertama yang hadir di dunia terjadi pada abad ke-15, yaitu berada di pertengahan zaman Islam. Ketika dikaitkan dalam kajian keislaman, sistem perbankan modern pada saat ini merupakan sebuah persoalan baru.

Bila dilihat dari sudut pandang hukum Islam maka perkara lembaga ini digolongkan menjadi masalah ijtihadiyyah.
Sebagai golongan dari masalah ijtihadiyyah maka perkara ini tidak dapat dilepaskan dari perbedaan pendapat di antara para pemikirpemikir Islam. Bunga dan implementasi akad merupakan suatu titik sentral permasalahan seputar keuangan, khususnya pada perbankan, faktor inilah yang menimbulkan perbedaan pendapat dari para pemikir Islam dalam menyikapi masalah tersebut.

Selama dua puluh tahun terakhir, metode-metode perdagangan berkembang dengan sangat pesat, keadaan ini bertepatan dengan peningkatan jumlah kekayaan yang dimiliki oleh negara-negara Timur Tengah dan sebagian Asia, dan bersamaan dengan itu pula terdapat penolakan terhadap praktek-praktek ekonomi Barat yang bersifat sekuler (Fogel, 2007). Sistem ekonomi konvensional pada prakteknya memiliki unsur-unsur yang disebut MAGHRIB (Maisyir, Gharar, Riba, dan Bathil) oleh karena itu muncullah Bank Syariah sebagai reaksi dari ketidakterimaan umat Islam.

Islam memiliki prinsip-prinsip dalam bermuamalah untuk menghindari pengoperasian bank dengan sistem riba. Salah satu hal yang mendasari lahirnya bank syariah adalah untuk menyelesaikan persoalan tehadap pertentangan antara bunga bank dan riba. Bank dan uang memiliki kaitan yang sangat penting, dan dalam pelaksanaannya harus memusnahkan ketidakadilan, ketidakjujuran, dan pengeksploitasian dari satu pihak ke pihak lainnya.

Secara filosofis melakukan kegiatan ekonomi merupakan fitrah manusia memenuhi kebutuhan hidupnya, baik kebutuhan primer (daruriyah), sekunder (hajjiyah), maupun tersier (tahsiniyyah). Sebab dengan kegiatan tersebut manusia 
dapat memperoleh harta benda dan dengan harta benda tersebut manusia dapat mempertahankan dan melangsungkan kehidupannya sebagai khalifah di muka bumi.

Penghapusan ketidakadilan dan penegakan keadilan dalam ekonomi merupakan inti dari dilarangnya riba. Penghapusan riba dalam jual beli dan utangpiutang adalah makna dari penghapusan riba dalam ekonomi Islam. Segala bentuk transaksi yang memiliki sifat spekulatif dalam pembahasan ini dan terdapat unsurunsur gharar di dalamnya haruslah dilarang. Hal lain yang juga harus dihapuskan dalam sebuah perekonomian adalah bunga, karena bunga termasuk ke dalam kategori riba nasi'ah.

Eksistensi dan kekuatan ekonomi Islam ini telah diakui oleh para pemikir ekonomi Barat sejak zaman dahulu, bahkan bapak ekonomi dunia yaitu Adam Smith mengabadikannya di dalam buku yang ditulisnya, yang berjudul Wealth of Nation. Secara terperinci ia mengisahkan bagaimana para pedagang Muslim melakukan transaksi perdagangan ketika memasuki suatu kota. Di dalam bukunya tersebut Adam Smith membagi tingkat perekonomian masyarakat ke dalam dua kategori, yaitu masyarakat dengan ekonomi yang terbelakang dan masyarakat dengan ekonomi yang maju, dan di dalam bukunya bangsa Arab yang dipimpin oleh Nabi Muhammad shalallahu 'alaihi wa sallam dan generasi sesudahnya merupakan contoh dari masyarakat dengan ekonomi yang maju.

Banyaknya ilmuwan ekonomi Islam dan adanya pengelompokan pemikiran dari berbagai pemikiran ilmuwan tersebut diimbangi dengan semakin banyaknya dan beragamnya sumber literasi ekonomi Islam yang dihasilkan. Keberadaan sumber literasi yang begitu banyak di bidang ekonomi Islam ini tidak diimbangi dengan upaya yang menyeluruh untuk membandingkan pemikiran-pemikiran para ekonom Muslim. Perbandingan tersebut harus berdasarkan pada pemahaman mereka tentang konsep dasar tentang riba dan perbankan.

Kuatnya sistem ekonomi konvensional dan adanya perbedaan pandangan yang disampaikan oleh para ahli ekonomi Islam kontemporer serta adanya perbedaan latar belakang keilmuwan di antara para ahli ekonomi Islam. Di sisi lain masih minimnya usaha yang menyeluruh untuk dapat mengkomparasi dan mengelompokkan pemikiran-pemikiran para ahli tentang bagaimana konsep-konsep Islam tentang riba dan perbankan. Hal inilah yang menjadi pendorong untuk melaksanakan analisis komparatif pemikiran antara $\mathrm{M}$. Umer Chapra dan M. Abdul Mannan. Penelitian ini didasari oleh motif pemikiran apakah M. Umer Chapra dan M. Abdul Mannan yang keduanya berasal dari Pakistan serta memiliki latar belakang ilmu yang berasal dari Barat (Amerika Serikat) dan termasuk dalam kalangan madzhab mainstream mempunyai kesamaan ataukah ada variasi atau ragamnya dalam masalah yang sangat penting, yaitu tentang konsep riba dan perbankan.

\section{B. TINJAUAN PUSTAKA}

\section{Bunga}

Menurut Widyaningsih, et.al (2015), definisi dari bunga dalam The American Heritage Dictionary of The English Languange yaitu "a charge for a financial loan, usually a percentage of the amount loaned". Definisi lain tentang bunga juga disebutkan dalam Oxford English 
Dictionary yang dikutip oleh Rahmawaty (2013), yaitu "money paid for use of money lent (the principal) or for forbearance of a debt, according to a fixed ratio (rate per cent)". Tim Pengembangan Perbankan Syariah Institut Bankir Indonesia (2011) mengutip definisi bunga menurut The Legal Encyclopedia for Home and Business sebagai "compensation for use of money which is due". Sedangkan Muhammad (2016) dalam bukunya yang berjudul Bank Syariah: Analisis Kekuatan, Kelemahan, Peluang, dan Ancaman mengartikan bunga sebagai berikut: "Bunga adalah tanggungan pada pinjaman uang yang biasanya dinyatakan dalam persentase dari uang yang dipinjamkan atau sejumlah uang yang dijumlahkan atau dikalkulasikan untuk penggunaan modal yang dinyatakan dengan persentase dan kaitannya dengan suku bunga."

Secara garis besar, setelah melihat seluruh penjelasan di atas, bunga dapat diartikan sebagai balas jasa atas pemakaian dana.

\section{Riba}

Menurut bahasa, riba dapat diartikan sebagai tambahan (ziyadah). Maksud dari tambahan dalam definisi riba menurut bahasa adalah tambahan yang berasal dari usaha haram yang merugikan salah satu pihak dalam suatu transaksi (Sura'i, 1993). Jika melihat dari pengertian lain, secara linguistik, riba dapat pula diartikan sebagai tumbuh dan membesar. Adapun menurut istilah teknis, riba memiliki makna yaitu pengambilan tambahan dari harta pokok atau modal secara batil (Antonio, 2017).

Kamus besar bahasa Indonesia mengartikan riba sebagai kelebihan atau peningkatan atau surplus. Tetapi menurut sudut pandang ilmu ekonomi, riba merujuk pada kelebihan dari jumlah uang pokok yang dipinjamkan oleh pemberi pinjaman dari peminjam. Islam sendiri mengartikan riba sebagai suatu kelebihan yang diminta dengan cara yang khusus (Nafik, 2009). Kata riba dalam bahasa Arab dapat berarti tambahan meskipun sedikit di atas jumlah uang yang dipinjamkan, hingga mencakup sekaligus riba dan bunga. Riba dalah hal ini semakna dengan kata usury dalam bahasa Inggris yang dalam penggunaan modern berarti suku bunga yang lebih dari biasanya atau suku bunga yang mencekik.

Setelah melihat dari berbagai definisi yang telah dipaparkan di atas, dapat disimpulkan bahwa riba adalah suatu kegiatan pengambilan nilai tambah yang memberatkan dari akad perekonomian, seperti jual beli atau utang piutang, dari penjual terhadap pembeli atau dari pemiliki dana kepada peminjam dana, baik diketahui bahkan tidak diketahui, oleh pihak kedua. Riba dapat juga diartikan hanya sebatas pada nilai tambah dari nilai pokok dalam suatu akad perekonomian.

\section{Hubungan Bunga dan Riba}

Sejarah ekonomi Eropa membedakan makna dari 'usury' atau riba dengan 'interest' atau bunga. Kata 'usury' diartikan sebagai kegiatan meminjamkan uang "where more is asked than is given". Kata 'usury' berasal dari bahasa Latin yaitu 'usura' yang memiliki arti 'use' atau menggunakan sesuatu. Secara sederhana, usury dimaknai sebagai harga yang harus dibayarkan untuk menggunakan uang.

Sedangkan kata 'interest' memiliki asal kata dari bahasa Latin yaitu 'intereo' yang memiliki arti untuk kehilangan "to be lost". Sebagian yang lain mengatakan bahwa interest memiliki asal kata dari bahasa Latin yaitu 'interesee' yang memiliki arti datang di tengah "to come in between" yaitu kompensasi kerugian yang muncul di 


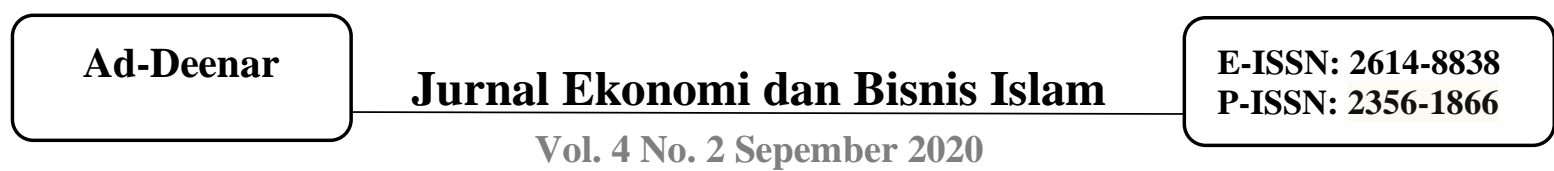

Vol. 4 No. 2 Sepember 2020

tengah transaksi jika peminjam tidak mengembalikan sesuai waktu (compensation or penalty for delayed repayment of a loan). Pada perkembangan selanjutnya, 'interest' bukan saja diartikan sebagai ganti rugi akibat keterlambatan pembayaran utang, tetapi diartikan juga sebagai ganti rugi atas kesempatan yang hilang (opportunity loss) (Rivai, et.al, 2007).

Jika melihat definisi di atas, terlihat jelas bahwa usury dan interest yang dikenal saat ini pada hakikatnya adalah sama. Keduanya memiliki arti tambahan uang, umumnya dalam persentase. Istilah 'usury' muncul dikarenakan belum mapannya pasar keuangan pada zaman itu, sehingga penguasa harus menetapkan suatu tingkat bunga yang dianggap 'wajar'. Namun, setelah mapannya lembaga dan pasar keuangan, kedua istilah itu menjadi hilang karena hanya ada satu tingkat bunga di pasar sesuai dengan hukum permintaan dan penawaran.

Permasalahan antara bunga dan riba sudah sering sekali dibahas oleh para ulama, baik oleh ulama tekstual maupun oleh ulama kontekstual. Hal tersebut tidak terlepas dari persoalan dasar hukum Islam pada bidang muamalah yang diatur oleh nash syariah hanya secara umum (global), tidak dijelaskan secara khusus atau rinci (detail), berbeda dengan persoalan ibadah dan aqidah yang bersifat tafsil. Berkaitan dengan hukum bunga, yang menjadi inti permasalahan adalah perbedaan pandangan di kalangan ulama dalam menentukan illat hukum tentang riba. Beberapa kalangan ulama memakai illat 'ziyadah' atau tambahan dan beberapa ulama lain memakai illat 'dzulm' atau kemudharatan. Penentuan illat hukum bunga ini menjadikan ulama terbagi menjadi dua kelompok, yaitu kelompok NeoRevivalisme dan kelompok Modernis.

\section{Perbankan}

Bank memiliki asal kata yang berasal dari Bahasa Italia yaitu banco dan bisa juga berasal dari Bahasa Prancis yaitu bangue, kedua kata tersebut memiliki arti peti / lemari atau bangku. Makna dari kedua kata tersebut di atas mencerminkan fungsi dasar yang dimiliki oleh bank, yaitu pertama, menyediakan tempat untuk menitipkan uang dengan aman (safe keeping function), kedua, menyediakan alat pembayaran untuk membeli barang dan jasa (transaction function) (Antonio, 2006). Bank di dalam kamus besar bahasa Indonesia memiliki arti sebagai suatu lembaga keuangan yang usaha pokoknya memberikan kredit dan jasa dalam lalu lintas pembayaran dan peredaran uang.

\section{Aliran-Aliran dalam Ekonomi Islam}

Pada tahun 1930-an ekonomi Islam kembali bergeliat menancapkan eksistensinya sebagai salah satu bangunan ilmu yang kukuh dan mampu menjawab berbagai permasalahan-permasalahan ekonomi kontemporer. Jika melihat ke dalam konteks wacana pemikiran ekonomi Islam kontemporer, maka akan didapatkan ada tiga madzhab besar yang sangat mempengaruhi teori-teori ekonomi Islam. Madzhab-madzhab ekonomi ini memiliki pandangan yang berbeda terhadap permasalahan ekonomi. Pemahaman berbeda ini dilatarbelakangi oleh metode yang dipakainya. Ketiga madzhab tersebut adalah Baqir Al-Sadr, mainstream, dan alternatif-kritis.

Madzhab Baqir Al-Sadr dipelopori oleh Muhammad Baqir Al-Sadr dengan bukunya yang berjudul Iqtishaduna. Tokoh-tokohnya yaitu Muhammad Baqir Al-Sadr, Ali Syariati, Abbas Mirakhor, 


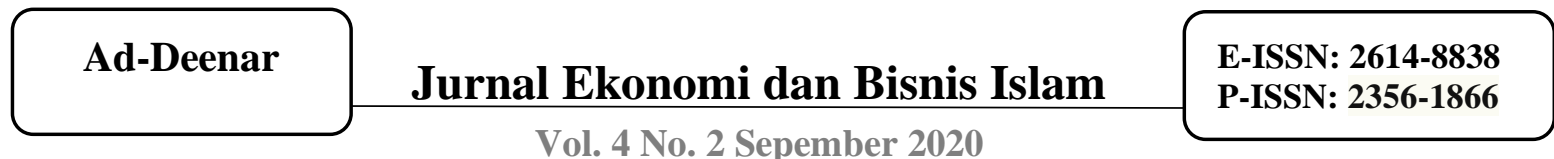

Vol. 4 No. 2 Sepember 2020

Baqir Al-Hasani, Kadim Al-Sadr, Iraj Toutounchian, dan Hedayati. Madzhab ini berpendapat bahwa permasalahan dalam ekonomi muncul karena adanya distribusi yang tidak merata dan tidak adil. Madzhab ini juga menolak anggapan bahwa kebutuhan manusia sifatnya tidak terbatas.

Madzhab mainstream dipelopori oleh M. Umer Chapra, M. Abdul Mannan, Metwally, Monzer Kahf, Fahim Khan, dan M. Nejatullah Siddiqi. Madzhab ini berpendapat bahwa masalah ekonomi muncul karena sumber daya yang terbatas dihadapakan pada keinginan manusia yang tidak terbatas. Perbedaannya hanya dalam penyelesaian masalah ekonomi tersebut. Masalah kelangkaan sumber daya menyebabkan manusia harus melakukan pilihan.

Madzhab alternatif-kritis dipelopori oleh Timur Kuran, Jomo Kwame Sundaram, Muhammad Arif, dan lain-lain. Madzhab ini berpendapat bahwa analisis kritik bukan saja harus dilakukan terhadap ekonomi konvensional (sosialis dan kapitalis) yang telah ada, tetapi juga terhadap ekonomi Islam sendiri.

\section{METODE PENELITIAN}

\section{Desain Penelitian}

Metodologi yang digunakan dalam penelitian ini adalah metode kualitatif. Jenis penelitian ini adalah kepustakaan (library research). Data-data yang dibutuhkan untuk menjalankan jenis penelitian kepustakaan (library research) ini berasal dari buku-buku, jurnal penelitian, karangan ilmiah, ensiklopedia serta sumber-sumber tertulis lainnya, baik berupa media cetak ataupun media elektronik.

$\begin{array}{lcr}\quad \text { Penelitian } & \text { ini } & \text { menggunakan } \\ \text { pendekatan } & \text { analisis } & \begin{array}{r}\text { komprataif } \\ \text { (comparative }\end{array} \\ \text { analysis). } & \text { Penelitian ini }\end{array}$

berusaha untuk membandingkan pemikiran tokoh ekonom Muslim M. Umer Chapra dan M. Abdul Mannan tentang konsep riba dan perbankan. Analisis komparasi ini akan menghasilkan suatu konsep yang berisi kesamaan filosofi dasar yang disepakati oleh tokoh ekonomi Islam serta hal-hal yang berbeda dari pemikiran tokoh ekonomi Islam dalam konsep riba dan perbankan.

\section{Jenis dan Sumber Data}

Penelitian ini menggunakan jenis data primer dan data sekunder. Data primer pada penelitian ini berasal dari buku-buku maupun jurnal-jurnal penelitian lainnya karya M. Umer Chapra dan M. Abdul Mannan. Buku utama yang menjadi sumber data dari penelitian ini adalah karya $\mathrm{M}$. Umer Chapra dan M. Abdul Mannan yang berjudul:

a. The Future of Economics: An Islamic Perspective, (Islamic Foundation, 2000) karya Umer Chapra

b. Masa Depan Ilmu Ekonomi: Sebuah Tinjauan Islam, (Aqwam, 2018) karya M. Umer Chapra yang diterjemahkan oleh Ikhwan Abidin Basri

c. Islam dan Tantangan Ekonomi, (Aqwam, 2018) karya M. Umer Chapra yang diterjemahkan oleh Ikhwan Abidin Basri

d. Sistem Moneter Islam, (Aqwam, 2018) karya M. Umer Chapra yang diterjemahkan oleh Ikhwan Abidin Basri

e. Teori dan Praktek Ekonomi Islam, (Dana Bakti Prima Yasa, 1995) karya M. Abdul Mannan yang diterjemahkan oleh M. Nastangin

Sedangkan untuk data sekunder, yaitu menggunakan seluruh sumber literasi yang 
terkait dengan ekonomi Islam secara umum atau sumber literasi yang dapat memberikan informasi tambahan sesuai dengan judul yang diangkat dalam penelitian ini. Bentuknya dapat berupa majalah, buku, jurnal, artikel, dan yang lainnya.

\section{Analisis Data}

Penelitian ini menggunakan Teknik analisis data kualitatif yaitu menggunakan metode analisis isi (content analysis) dan komparatif. Metode analisis isi (content analysis) adalah suatu metode yang dipakai untuk meneliti dokumentasi data yang berupa teks, gambar, symbol, dan sebagainya dalam hal ini berupa teks yang terdapat dalam buku mengenai pemikiran M. Umer Chapra dan M. Abdul Mannan perihal konsep riba dan perbankan.

Sementara teknik analisis komparatif merupakan teknik analisis dengan cara membandingkan hasil pemikiran dari $\mathrm{M}$. Umer Chapra dan M. Abdul Mannan mengenai konsep riba dan perbankan dengan menggunakan beberapa dimensi isi dari kedua tokoh ini. Untuk mengkomparasikan pemikiran M. Umer Chapra dan M. Abdul Mannan peneliti menggunakan analisis himpunan, dalam hal ini digunakan konsep interseksi union.

\section{Gambar 1}

\section{Diagram Venn Menunjukkan Interseksi}

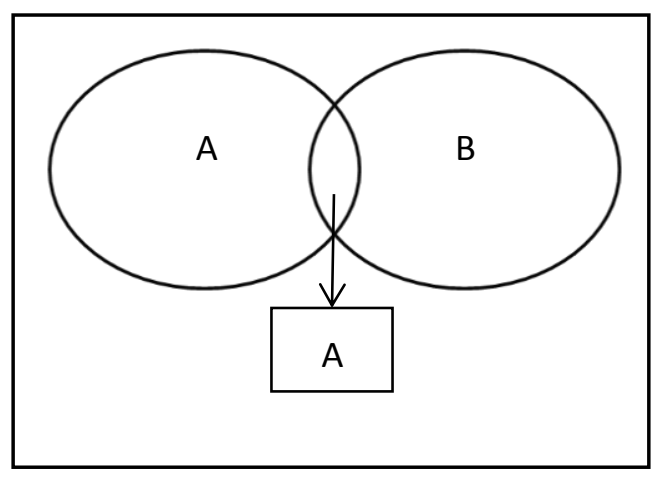

\section{PEMBAHASAN}

\section{Analisis Pemikiran M. Umer Chapra} Terhadap Riba dan Perbankan

\section{1a. Riba}

Riba secara literal memiliki arti bertambah, berkembang, atau tumbuh. Akan tetapi tidak setiap penambahan atau pertumbuhan itu dilarang oleh Islam. Dalam syariah Islam, riba secara teknis mengacu kepada pembayaran 'premi' yang harus dibayarkan oleh peminjam kepada pemberi pinjaman disamping pengembalian pokok sebagai syarat pinjaman atau perpanjangan atas jatuh tempo. Riba terbagi menjadi dua ketegori, yaitu riba nasi'ah dan riba fadhl.

Istilah riba mengandung arti bunga dalam segala manifestasinya dengan mengabaikan apakah bunga itu berkaitan dengan pinjaman untuk konsumsi atau untuk tujuan-tujuan produktif, apakah pinjaman itu bersifat personal atau komersial, apakah pinjaman itu sebuah pemerintahan, individu swasta atau perusahaan, dan apakah suku bunga itu rendah atau tinggi.

Riba telah menimbulkan dampak negatif bagi perekonomian negara. Riba dalam bentuk bunga memainkan peranan penting dalam mengakibatkan timbulnya krisis. Berikut adalah beberapa dampak negatif riba:

1. Riba telah menyebabkan timbulnya ketidakadilan dalam masyarakat, terutama bagi para pemilik modal yang menerima keuntungan tanpa mendapatkan resiko.

2. Keburukan riba juga disebabkan karena riba yang berwujud bunga dapat menambah biaya produksi bagi para pengusaha yang menggunakan modal pinjaman dari bank atau lembaga pinjaman lainnya. Biaya produksi yang tinggi mengakibatkan 


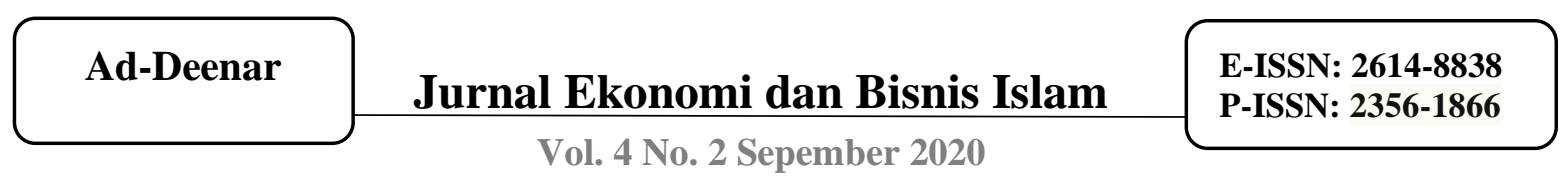

Vol. 4 No. 2 Sepember 2020

perusahaan menjual produknya dengan harga yang lebih tinggi. Naiknya tingkat harga akan berakibat pada terjadinya inflasi akibat lemahnya daya beli konsumen.

3. Riba juga menjadi penyebab utama ketidakstabilan nilai mata uang (currency) suatu negara. Hal ini dikarenakan uang senantiasa berpindah dari negara yang memiliki tingkat suku bunga riil yang rendah ke negara yang memiliki tingkat suku bunga riil yang lebih tinggi. Hal ini diakibatkan oleh para spekulator ingin memperoleh keuntungan besar dengan menyimpan uangnya di tempat yang tingkat suku bunganya relatif tinggi.

Alternatif dari riba adalah dengan lebih banyak mengandalkan pada modal sendiri (equity) dan sedikit pada kredit. Hal ini terdiri dari kombinasi mode-mode primer seperti Mudharabah (kemitraan pasif), Musyarakah (kemitraan aktif), dan modelmodel sekunder seperti Murabahah (cost plus service charge), Ijarah (sewa), Ijarah wa Iqtina (sewa-beli), Salam (forward delivery contract), dan Istishna (contracted production).

\section{1b. Perbankan}

Bank syariah merupakan suatu instrumen pendukung dalam sistem keuangan Islam. Bank syariah dengan sistem corporate governance dan manajamen yang baik, akan memperkuat pergerakan keuangan Islam, meminimalisir kegagalan dan diharapkan mampu mewujudkan keadilan sosio-ekonomi dengan pelarangan bunga. Sedangkan dalam melakukan standarisasi produk dan jasa, bank syariah hendaknya mengadakan forum diskusi antara ulama fiqih, sebagaimana dengan yang dilaksanakan oleh IDB dengan membuat lembaga diskusi yang disebut Council of Islamic Bank.

Penghapusan riba akan menjadi perbedaan yang esensial antara bank komersial berbasis bunga dan bank Islam, tetapi hal ini tidak akan menjadi satusatunya perbedaan diantara keduanya. Hakikat, pandangan, dan operasi bank komersial akan mengalami transformasi total.

1. Kegiatan bank sentral pada prinsipnya didasarkan pada penggunaan dana publik, penting bahwa kepentingan publik dan bukan kepentingan individu atau kelompok yang harus dilayani oleh bank komersial Islam.

2. Bank Islam harus menggunakan semua deposito yang berasal dari publik untuk memenuhi kepentingan publik dan merealisasikan sasaran sosio-ekonomi Islam.

3. Bank Islam akan bersifat universal atau suatu bank yang memiliki tujuan ganda dan bukan sekedar bank komersial. Mereka adalah gabungan antara bank komersial dan bank investasi, dan akan menawarkan serangkaian produk pelayanan bagi para pelanggan yang mempunyai hubungan jangka panjang.

4. Bank Islam akan melakukan evaluasi yang hati-hati terhadap permohonan pembiayaan yang berorientasi kepada penyertaan modal.

5. Sistem bagi hasil akan cenderung mempererat hubungan antara bank dan pengusaha yang merupakan tonggak bank multi tujuan.

Seperti halnya dengan bank konvensional, bank-bank Islam harus juga memobilisasi sumber-sumber daya melalui deposito unjuk dan deposito mudharabah 
(tabungan, deposito berjangka atau tetap). Semakin besar keberhasilan bank Islam dalam hal ini, semakin besar pelayanan yang harus diberikan kepada umat. Di samping pembiayaan mudharabah dan syirkah serta investasi dalam saham perusahaan perseroan, bank dihadapkan pada keperluan abadi untuk melakukan diversifikasi portofolionya. Aternatifalternatif ini akan cenderung menempati proporsi portofolio bank lebih besar pada tahapan inisialnya dan akan berkurang secara gradual seiring dengan perjalanan waktu dan akumulasi pengalaman dalam perbankan Islam.

1. Alternatif pertama adalah leasing. Ada dua bentuk leasing, yaitu financial leasing dan operating leasing. Suatu financial leasing melibatkan sebuah perjanjian yang tidak dapat dibatalkan antara bank dan pelanggan dimana bank akan melakukan pembelian suatu aset tertentu dan menyewakannya (lease) serta memberikan kuasa kepada pelanggan untuk jangka waktu menengah atau panjang.

2. Alternatif kedua adalah pelelangan investasi. Hal ini melibatkan penyiapan suatu kajian kelayakan yang rinci terhadap suatu proyek oleh sebuah bank atau suatu konsorsium dan memberikan pembiayaan yang dituntut oleh proyek ini kepada penawar tertinggi.

3. Alternatif ketiga adalah ba'i al muajjal dan ba'i al murabahah. Ba'i al muajjal mengacu kepada suatu penjualan yang pembayarannya ditangguhkan (baik dibayar secara tunai maupun diangsur). Ba'i al murabahah dalam bentuknya yang paling sederhana merujuk kepada salah satu dari tiga kemungkinan dalam bentuk penjualan. Salah satu kemungkinan ini adalah murabahah yang berarti memasok barang oleh penjual kepada pembeli dengan suatu margin keuntungan tertentu yang disetujui oleh kedua belah pihak.

Seperti halnya dengan bank-bank sentral lainnya, bank sentral Islam harus bertanggung jawab untuk mengeluarkan uang dengan koordinasi dengan pemerintah, mengusahakan stabilitas internal dan eksternalnya. Ia harus melakukan persiapan untuk kliring dan penyelesaian cek dan transfer, dan harus bertindak sebagai lender of last resort. Ia harus membimbing, melakukan supervisi dan regulasi bank-bank komersial, lembaga keuangan non-bank dan lembaga kredit khusus, korporasi asuransi deposito dan korporasi audit investasi tanpa harus mengganggu otonomi-otonomi lembaga ini. Tidak seperti bank sentral konvensional, ia juga bertanggungjawab menutup kemungkinan konsentrasi kekayaan dan kekuasaan ditangan segelintir vested interest melalui lembaga finansial.

\section{Analisis Pemikiran M. Abdul Mannan Terhadap Riba dan Perbankan}

\section{2a. Riba}

Arti bebas dari istilah riba adalah pertambahan atau pertumbuhan, namun arti ini tidaklah berguna bagi tujuan pembahasan ini, karena setiap pertambahan seperti halnya pertambahan yang berasal dari perdagangan dan industri tidaklah dilarang. Tetapi digunakannya kata sandang 'al' di depan riba dalam Al Qur'an menunjukkan kenyataan bahwa al riba mengacu pada perbuatan mengambil sejumlah uang yang berasal dari seseorang yang berutang secara berlebihan.

Sebetulnya, tidak ada perbedaan antara bunga dan riba. Islam dengan tegas melarang semua bentuk bunga betapapun 
hebat dan meyakinkannya nama yang diberikan padanya. Perbedaan antara riba dalam Al Qur'an dengan bunga dalam masyarakat kapitalis hal itu hanya merupakan ekses atas modal yang dipinjam. Memang benar, riba dianggap tidak canggih dibandingkan dengan bunga. Tetapi menyebut riba dengan nama bunga yang tidak mengubah sifatnya.

Riba memiliki dampak yang negatif bagi kehidupan negara dan masyarakat. Berikut adalah beberapa dampak negatif riba:

1. Riba yang berbentuk bunga adalah penyebab dari pertumbuhan kapitalis dalam masyarakat. Kelas kapitalis yang perkasa ini menginvestasikan modal mereka sendiri bersama dengan modal orang lain, mereka memastikan bahwa bagian terbesar produksi adalah untuk mereka sendiri. Dalam proses produksi ini, kelas kapitalis menjadi begitu kuat sehingga ia menguasai semua kemungkinan dari kehidupan manusia. Terakhir, kaum kapitalis merusak kehidupan politik suatu bangsa dengan kediktatoran mereka dalam kehidupan perekonomian masyarakat.

2. Riba yang berbentuk bunga menghalangi penempatan lebih penuh akan sumber-sumber dana dan mengakibatkan pengangguran dalam masyarakat. Hal ini menimbulkan pengangguran dari segi penyediaan maupun permintaan akan dana investasi.

3. Tanpa memberi sumbangan aktif pada produksi, golongan kapitalis tumbuh subur dan makmur melalui bunga. Bunga merupakan suatu sarana pendapatan tanpa kerja yang mencolok. Hal ini merupakan bentuk perampasan dan pengeksploitasian, karena bunga masuk sebagai biaya produksi, oleh karena itu memperlambat pulihnya keadaan jika depresi menyerang perniagaan, perdagangan, dan industri.
Alternatif untuk sistem riba yang berbentuk bunga adalah mengalihkannya kepada sistem mudharabah, yang merupakan bagi hasil dan sekaligus berkeadilan. Dengan mudharabah, tidak saja semangan Qur'ani akan lebih terpenuhi, namun, pada saat yang sama penciptaan lapangan kerja dan pembangkit kegiatan ekonomi akan lebih sejalan dengan norma kerja sama menurut Islam. Bukan saja mudharabah, alternatif lainnya adalah musyarakah, ijarah, kafalah, wakalah, dan sebagainya.

\section{2b. Perbankan}

Kedudukan bank Islam dalam hubungan dengan para kliennya adalah sebagai mitra investor dan pedagang, sedangkan dalam hal bank di Barat, hubungannya adalah sebagai kreditur dan debitur. Perbankan Islam didasarkan atas prinsip syirkah (mitra usaha) yang telah diakui di seluruh dunia. Artinya, seluruh sistem perbankan di mana pemegang saham, depositor, investor, dan peminjam akan berperan serta atas dasar mitra usaha.

Mekanisme perbankan Islami yang berdasarkan mitra usaha adalah bebas bunga. Oleh karena itu soal membayarkan bunga kepada para depositor atau pembebanan suatu bunga dari para klien tidak akan timbul. Dalam rencana perbankan Islami, mungkin terdapat dua jenis depositor.

1. Depositor yang dapat mendeposit dana surplusnya, ia diperkenankan menarik dananya setiap waktu tanpa pemberitahuan. Jenis deposito ini hanya untuk penyimpanan keamanan (safe depositing), bukan untuk investasi dalam suatu kegiatan produksi yang mengandung resiko.

2. Depositor yang tidak boleh menarik dana mereka tanpa pemberitahuan. Dana surplus mereka mungkin 
diinvestasikan dalam urusan produksi atas dasar jangka pendek.

Dalam menjalankan pekerjaan yang sesungguhnya, bank Islam menggunakan berbagai teknik dan metode investasi seperti kontrak mudharabah. Bank Islam juga melihat dalam kontrak murabahah (berdasarkan perhitungan biaya ditambah sesuatu atau cost plus). Islam juga berurusan dengan pasar devisa dan melaksanakan jasa perbankan lainnya seperti surat kredit dan surat jaminan. Mungkin bank juga memberikan jasa bukan perbankan seperti trust business, real estate, dan jasa konsultan. Selain dari yang disebutkan di atas, bank dapat memobilisasi sumber dayanya untuk usaha jasa non-bank dan kegiatan non-bank, yaitu:

1. Jasa perantara yang diberikan oleh bank modern terutama terdiri dari membeli dan menjual surat berharga di bursa efek, melakukan dan menerima pembayaran sewa, uang langganan, deviden, bayaran sekolah dan kuliah, bertindak sebagai wali, pelaksana wasiat dan pengacara, juga menjadi koresponden dan wakil. Ada bermacam-macam keperluan umum lainnya yang terpenting adalah menerima barang berharga untuk disimpan dengan jaminan, melakukan transaksi urusan devisa, penjamin emisi surat efek, bertindak sebagai wasit, dan sebagainya.

2. Peran serta bank dalam proses pertumbuhan ekonomi dengan menginvestasikan sebagian sumber daya seadanya dalam pendidikan dan lembaga sosial lain, untuk ini mungkin bank tidak menerima keuntungan langsung. Bank Islam adalah suatu lembaga sosial yang sangat penting, maka ia harus memiliki tanggung jawab terhadap perkembangan sosial. Pendidikan merupakan komponen utama perkembangan sosial dan suatu proses yang digunakan untuk mencapai pertumbuhan ekonomi.

Seperti telah kita ketahui Baitul Mal merupakan bank sentral. Hal ini tidak berarti bahwa ia memiliki semua fungsi bank sentral dewasa ini, tetapi fungsi yang terdapat dalam bentuk primitif dilaksanakannya. Terdapat dua macam kewajiban Baitul Mal sebagai perbendaharaan negara, yaitu:

1. Mengamankan harta benda yang disimpan dalam perbendaharaan.

2. Mengurus penerimaan kekayaan perbendaharaan: (a) Mengurut nilai yang diterima, umpamanya dengan cara kompensasi untuk membayar para serdadu atau harga senjata dan kuda, (b) Mengurus kepentingan umum

Baitul Mal telah biasa membayar semua kebutuhan dan keperluan masyarakat, dan ia sudah melaksanakan fungsi yang hampir serupa dengan dengan yang dilakukan oleh bank sentral dewasa ini, kecuali pengeluaran uang, pengadaan kredit, dan pengawasan suku bunga. Soal mata uang merupakan sarana modern dan mudah dicocokkan dalam fungsi Baitul Mal karena dalam fungsi ini suku bunga tidak memainkan suatu bagian apapun.

Sistem perbankan sentral dengan suatu rencana Islam tentang masyarakat akan menjadi lebih sederhana dan lebih mudah daripada selama ini, karena bank tidak memberi terlalu tekan pada kontrol kredit dengan menaikkan atau menurunkan suku bunga, ikut serta dalam operasi pasar-pasar terbuka, dan mengubah-ubah bank rasio cadangan bank-bank anggota. Bank sentral 


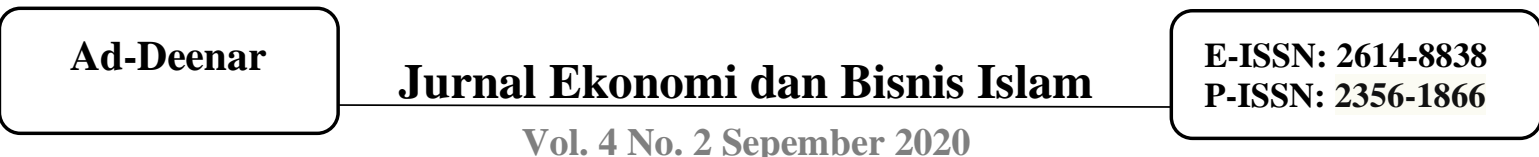

Vol. 4 No. 2 Sepember 2020

Islam tidak akan menggunakan semua cara demikian, karena tidak memerlukan penerapan bunga.

3. Perbedaan Konsep Riba dan Perbankan M. Umer Chapra dan M. Abdul Mannan

3a. Dimensi dan Aspek Pemikiran M. Umer Chapra dan M. Abdul Mannan
Berikut ini merupakan tabel dimensi dan aspek-aspek pemikiran M. Umer Chapra dan M. Abdul Mannan tentang keseluruhan wilayah analisis yang dijadikan anggota dari dua buah himpunan, yaitu himpunan M. Umer Chapra dan Himpunan M. Abdul Mannan:

Tabel 1

Himpunan M. Umer Chapra (UC)

\begin{tabular}{|c|c|c|}
\hline No. & Dimensi & Aspek-Aspek \\
\hline \multirow[t]{3}{*}{1} & \multirow[t]{3}{*}{$\begin{array}{l}\text { Konsep Riba } \\
\text { a. Definisi Riba (DR- } \\
\text { UC) } \\
\text { b. Riba dan Bunga } \\
\text { (RB-UC) } \\
\text { c. Dampak Negatif } \\
\text { Riba (DNR-UC) } \\
\text { d. Alternatif Riba (AR- } \\
\text { UC) }\end{array}$} & $\begin{array}{l}\text { a. Riba secara literal memiliki arti bertambah, } \\
\text { berkembang, atau tumbuh. Akan tetapi tidak setiap } \\
\text { penambahan atau pertumbuhan itu dilarang oleh Islam. } \\
\text { Dalam syariah Islam, riba secara teknis mengacu } \\
\text { kepada pembayaran 'premi' yang harus dibayarkan } \\
\text { oleh peminjam kepada pemberi pinjaman disamping } \\
\text { pengembalian pokok sebagai syarat pinjaman atau } \\
\text { perpanjangan atas jatuh tempo. Riba terbagi menjadi } \\
\text { dua ketegori, yaitu riba nasi'ah dan riba fadhl. }\end{array}$ \\
\hline & & $\begin{array}{l}\text { b. Istilah riba mengandung arti bunga dalam segala } \\
\text { manifestasinya dengan mengabaikan apakah bunga itu } \\
\text { berkaitan dengan pinjaman untuk konsumsi atau untuk } \\
\text { tujuan-tujuan produktif, apakah pinjaman itu bersifat } \\
\text { personal atau komersial, apakah pinjaman itu sebuah } \\
\text { pemerintahan, individu swasta atau perusahaan, dan } \\
\text { apakah suku bunga itu rendah atau tinggi. }\end{array}$ \\
\hline & & $\begin{array}{l}\text { c. Riba telah menimbulkan dampak negatif bagi } \\
\text { perekonomian negara. Riba dalam bentuk bunga } \\
\text { memainkan peranan penting dalam mengakibatkan } \\
\text { timbulnya krisis. Berikut adalah beberapa dampak } \\
\text { negatif riba: } \\
\text { 1. Riba telah menyebabkan timbulnya ketidakadilan } \\
\text { dalam masyarakat, terutama bagi para pemilik } \\
\text { modal yang menerima keuntungan tanpa } \\
\text { mendapatkan resiko. } \\
\text { 2. Keburukan riba juga disebabkan karena riba yang } \\
\text { berwujud bunga dapat menambah biaya produksi } \\
\text { bagi para pengusaha yang menggunakan modal } \\
\text { pinjaman dari bank atau lembaga pinjaman lainnya. } \\
\text { Biaya produksi yang tinggi mengakibatkan } \\
\text { perusahaan menjual produknya dengan harga yang } \\
\text { lebih tinggi. Naiknya tingkat harga akan berakibat } \\
\text { pada terjadinya inflasi akibat lemahnya daya beli } \\
\text { konsumen. } \\
\text { 3. Riba juga menjadi penyebab utama ketidakstabilan } \\
\text { nilai mata uang (currency) suatu negara. Hal ini }\end{array}$ \\
\hline
\end{tabular}




\begin{tabular}{|c|c|c|}
\hline & & $\begin{array}{l}\text { dikarenakan uang senantiasa berpindah dari negara } \\
\text { yang memiliki tingkat suku bunga riil yang rendah } \\
\text { ke negara yang memiliki tingkat suku bunga riil } \\
\text { yang lebih tinggi. Hal ini diakibatkan oleh para } \\
\text { spekulator ingin memperoleh keuntungan besar } \\
\text { dengan menyimpan uangnya di tempat yang tingkat } \\
\text { suku bunganya relatif tinggi. }\end{array}$ \\
\hline & & $\begin{array}{l}\text { d. Alternatif dari riba adalah dengan lebih banyak } \\
\text { mengandalkan pada modal sendiri (equity) dan sedikit } \\
\text { pada kredit. Hal ini terdiri dari kombinasi mode-mode } \\
\text { primer seperti Mudharabah (kemitraan pasif), } \\
\text { Musyarakah (kemitraan aktif), dan model-model } \\
\text { sekunder seperti Murabahah (cost plus service charge), } \\
\text { Ijarah (sewa), Ijarah wa Iqtina (sewa-beli), Salam } \\
\text { (forward delivery contract), dan Istishna (contracted } \\
\text { production). }\end{array}$ \\
\hline \multirow[t]{2}{*}{2} & \multirow[t]{2}{*}{$\begin{array}{l}\text { Konsep Perbankan } \\
\text { a. Definisi Perbankan } \\
\text { (DP-UC) } \\
\text { b. Mekanisme } \\
\text { Perbankan (MP-UC) } \\
\text { c. Mobilisasi Sumber } \\
\text { Daya Perbankan } \\
\text { (MSDP-UC) } \\
\text { d. Bank Sentral (BS- } \\
\text { UC) }\end{array}$} & $\begin{array}{l}\text { a. Bank syariah merupakan suatu instrumen pendukung } \\
\text { dalam sistem keuangan Islam. Bank syariah dengan } \\
\text { sistem corporate governance dan manajamen yang } \\
\text { baik, akan memperkuat pergerakan keuangan Islam, } \\
\text { meminimalisir kegagalan dan diharapkan mampu } \\
\text { mewujudkan keadilan sosio-ekonomi dengan } \\
\text { pelarangan bunga. Sedangkan dalam melakukan } \\
\text { standarisasi produk dan jasa, bank syariah hendaknya } \\
\text { mengadakan forum diskusi antara ulama fiqih, } \\
\text { sebagaimana dengan yang dilaksanakan oleh IDB } \\
\text { dengan membuat lembaga diskusi yang disebut Council } \\
\text { of Islamic Bank. }\end{array}$ \\
\hline & & $\begin{array}{l}\text { b. Penghapusan riba akan menjadi perbedaan yang } \\
\text { esensial antara bank komersial berbasis bunga dan bank } \\
\text { Islam, tetapi hal ini tidak akan menjadi satu-satunya } \\
\text { perbedaan diantara keduanya. Hakikat, pandangan, dan } \\
\text { operasi bank komersial akan mengalami transformasi } \\
\text { total. } \\
\text { 1. Kegiatan bank sentral pada prinsipnya didasarkan } \\
\text { pada penggunaan dana publik, penting bahwa } \\
\text { kepentingan publik dan bukan kepentingan individu } \\
\text { atau kelompok yang harus dilayani oleh bank } \\
\text { komersial Islam. } \\
\text { 2. Bank Islam harus menggunakan semua deposito } \\
\text { yang berasal dari publik untuk memenuhi } \\
\text { kepentingan publik dan merealisasikan sasaran } \\
\text { sosio-ekonomi Islam. } \\
\text { 3. Bank Islam akan bersifat universal atau suatu bank } \\
\text { yang memiliki tujuan ganda dan bukan sekedar bank } \\
\text { komersial. Mereka adalah gabungan antara bank } \\
\text { komersial dan bank investasi, dan akan menawarkan } \\
\text { serangkaian produk pelayanan bagi para pelanggan } \\
\text { yang mempunyai hubungan jangka panjang. }\end{array}$ \\
\hline
\end{tabular}




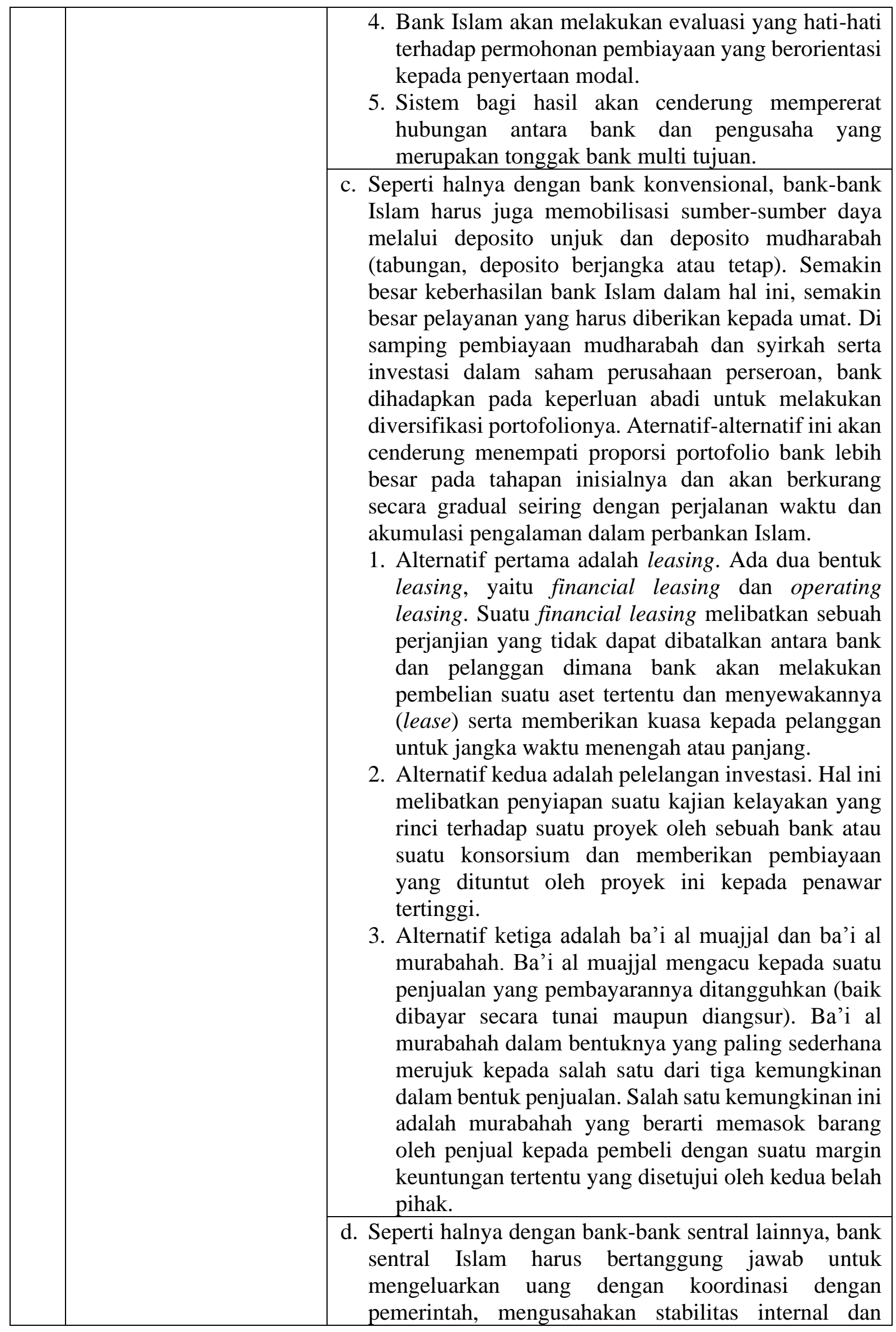




\begin{tabular}{|l|l|}
\hline & eksternalnya. Ia harus melakukan persiapan untuk \\
& kliring dan penyelesaian cek dan transfer, dan harus \\
bertindak sebagai lender of last resort. Ia harus \\
membimbing, melakukan supervisi dan regulasi bank- \\
bank komersial, lembaga keuangan non-bank dan \\
lembaga kredit khusus, korporasi asuransi deposito dan \\
korporasi audit investasi tanpa harus mengganggu \\
otonomi-otonomi lembaga ini. Tidak seperti bank \\
sentral konvensional, ia juga bertanggungjawab \\
menutup kemungkinan konsentrasi kekayaan dan \\
kekuasaan ditangan segelintir vested interest melalui \\
lembaga finansial.
\end{tabular}

Tabel 2

Himpunan M. Abdul Mannan (AM)

\begin{tabular}{|c|c|c|}
\hline No. & Dimensi & Aspek-Aspek \\
\hline \multirow[t]{3}{*}{$\mathbf{1}$} & \multirow[t]{3}{*}{$\begin{array}{l}\text { Konsep Riba } \\
\text { a. Definisi Riba (DR- } \\
\text { AM) } \\
\text { b. Riba dan Bunga } \\
\text { (RB-AM) } \\
\text { c. Dampak Negatif } \\
\text { Riba (DNR-AM) } \\
\text { d. Alternatif Riba (AR- } \\
\text { AM) }\end{array}$} & $\begin{array}{l}\text { a. Arti bebas dari istilah riba adalah pertambahan atau } \\
\text { pertumbuhan, namun arti ini tidaklah berguna bagi } \\
\text { tujuan pembahasan ini, karena setiap pertambahan } \\
\text { seperti halnya pertambahan yang berasal dari } \\
\text { perdagangan dan industri tidaklah dilarang. Tetapi } \\
\text { digunakannya kata sandang 'al' di depan riba dalam Al } \\
\text { Qur'an menunjukkan kenyataan bahwa al riba mengacu } \\
\text { pada perbuatan mengambil sejumlah uang yang berasal } \\
\text { dari seseorang yang berutang secara berlebihan. }\end{array}$ \\
\hline & & $\begin{array}{l}\text { b. Sebetulnya, tidak ada perbedaan antara bunga dan riba. } \\
\text { Islam dengan tegas melarang semua bentuk bunga } \\
\text { betapapun hebat dan meyakinkannya nama yang } \\
\text { diberikan padanya. Perbedaan antara riba dalam Al } \\
\text { Qur'an dengan bunga dalam masyarakat kapitalis hal } \\
\text { itu hanya merupakan ekses atas modal yang dipinjam. } \\
\text { Memang benar, riba dianggap tidak canggih } \\
\text { dibandingkan dengan bunga. Tetapi menyebut riba } \\
\text { dengan nama bunga yang tidak mengubah sifatnya. }\end{array}$ \\
\hline & & $\begin{array}{l}\text { c. Riba memiliki dampak yang negatif bagi kehidupan } \\
\text { negara dan masyarakat. Berikut adalah beberapa } \\
\text { dampak negatif riba: } \\
\text { 1. Riba yang berbentuk bunga adalah penyebab dari } \\
\text { pertumbuhan kapitalis dalam masyarakat. Kelas } \\
\text { kapitalis yang perkasa ini menginvestasikan modal } \\
\text { mereka sendiri bersama dengan modal orang lain, } \\
\text { mereka memastikan bahwa bagian terbesar produksi } \\
\text { adalah untuk mereka sendiri. Dalam proses produksi } \\
\text { ini, kelas kapitalis menjadi begitu kuat sehingga ia } \\
\text { menguasai semua kemungkinan dari kehidupan } \\
\text { manusia. Terakhir, kaum kapitalis merusak } \\
\text { kehidupan politik suatu bangsa dengan kediktatoran } \\
\text { mereka dalam kehidupan perekonomian masyarakat. }\end{array}$ \\
\hline
\end{tabular}


Vol. 4 No. 2 Sepember 2020

\begin{tabular}{|c|c|c|}
\hline & & $\begin{array}{l}\text { 2. Riba yang berbentuk bunga menghalangi } \\
\text { penempatan lebih penuh akan sumber-sumber dana } \\
\text { dan mengakibatkan pengangguran dalam } \\
\text { masyarakat. Hal ini menimbulkan pengangguran } \\
\text { dari segi penyediaan maupun permintaan akan dana } \\
\text { investasi. } \\
\text { 3. Tanpa memberi sumbangan aktif pada produksi, } \\
\text { golongan kapitalis tumbuh subur dan makmur } \\
\text { melalui bunga. Bunga merupakan suatu sarana } \\
\text { pendapatan tanpa kerja yang mencolok. Hal ini } \\
\text { merupakan bentuk perampasan dan } \\
\text { pengeksploitasian, karena bunga masuk sebagai } \\
\text { biaya produksi, oleh karena itu memperlambat } \\
\text { pulihnya keadaan jika depresi menyerang } \\
\text { perniagaan, perdagangan, dan industri. }\end{array}$ \\
\hline & & $\begin{array}{l}\text { d. Alternatif untuk sistem riba yang berbentuk bunga } \\
\text { adalah mengalihkannya kepada sistem mudharabah, } \\
\text { yang merupakan bagi hasil dan sekaligus berkeadilan. } \\
\text { Dengan mudharabah, tidak saja semangan Qur'ani akan } \\
\text { lebih terpenuhi, namun, pada saat yang sama } \\
\text { penciptaan lapangan kerja dan pembangkit kegiatan } \\
\text { ekonomi akan lebih sejalan dengan norma kerja sama } \\
\text { menurut Islam. Bukan saja mudharabah, alternatif } \\
\text { lainnya adalah musyarakah, ijarah, kafalah, wakalah, } \\
\text { dan sebagainya. }\end{array}$ \\
\hline \multirow[t]{2}{*}{2} & \multirow[t]{2}{*}{$\begin{array}{l}\text { Konsep Perbankan } \\
\text { a. Definisi Perbankan } \\
\text { (DP-AM) } \\
\text { b. Mekanisme } \\
\text { Perbankan (MP- } \\
\text { AM) } \\
\text { c. Mobilisasi Sumber } \\
\text { Daya Perbankan } \\
\text { (MSDP-AM) } \\
\text { d. Bank Sentral (BS- } \\
\text { AM) }\end{array}$} & $\begin{array}{l}\text { a. Kedudukan bank Islam dalam hubungan dengan para } \\
\text { kliennya adalah sebagai mitra investor dan pedagang, } \\
\text { sedangkan dalam hal bank di Barat, hubungannya } \\
\text { adalah sebagai kreditur dan debitur. Perbankan Islam } \\
\text { didasarkan atas prinsip syirkah (mitra usaha) yang telah } \\
\text { diakui di seluruh dunia. Artinya, seluruh sistem } \\
\text { perbankan di mana pemegang saham, depositor, } \\
\text { investor, dan peminjam akan berperan serta atas dasar } \\
\text { mitra usaha. }\end{array}$ \\
\hline & & $\begin{array}{l}\text { b. Mekanisme perbankan Islami yang berdasarkan mitra } \\
\text { usaha adalah bebas bunga. Oleh karena itu soal } \\
\text { membayarkan bunga kepada para depositor atau } \\
\text { pembebanan suatu bunga dari para klien tidak akan } \\
\text { timbul. Dalam rencana perbankan Islami, mungkin } \\
\text { terdapat dua jenis depositor. } \\
\text { 1. Depositor yang dapat mendeposit dana surplusnya, } \\
\text { ia diperkenankan menarik dananya setiap waktu } \\
\text { tanpa pemberitahuan. Jenis deposito ini hanya untuk } \\
\text { penyimpanan keamanan (safe depositing), bukan } \\
\text { untuk investasi dalam suatu kegiatan produksi yang } \\
\text { mengandung resiko. } \\
\text { 2. Depositor yang tidak boleh menarik dana mereka } \\
\text { tanpa pemberitahuan. Dana surplus mereka mungkin }\end{array}$ \\
\hline
\end{tabular}


Vol. 4 No. 2 Sepember 2020

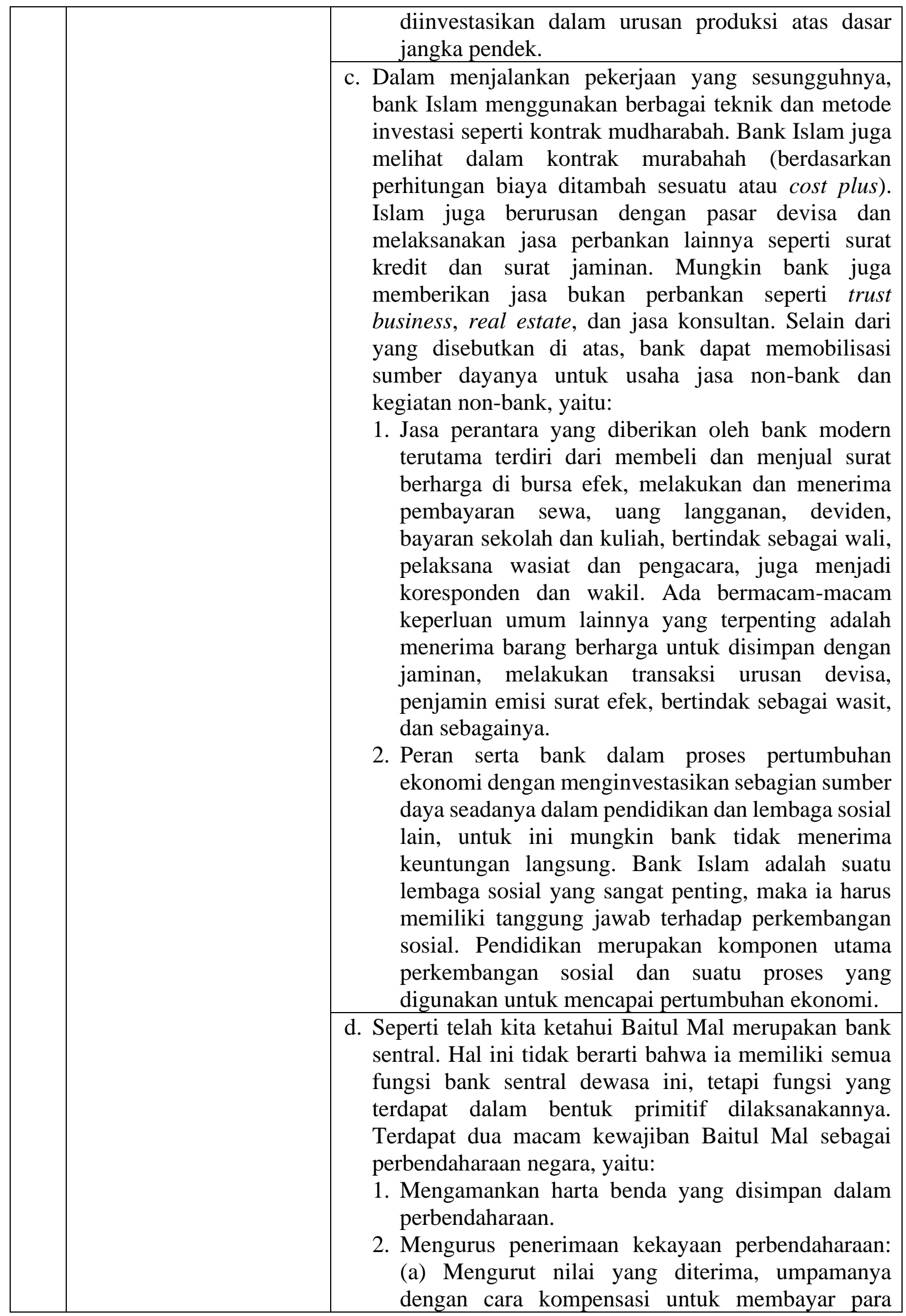


Vol. 4 No. 2 Sepember 2020

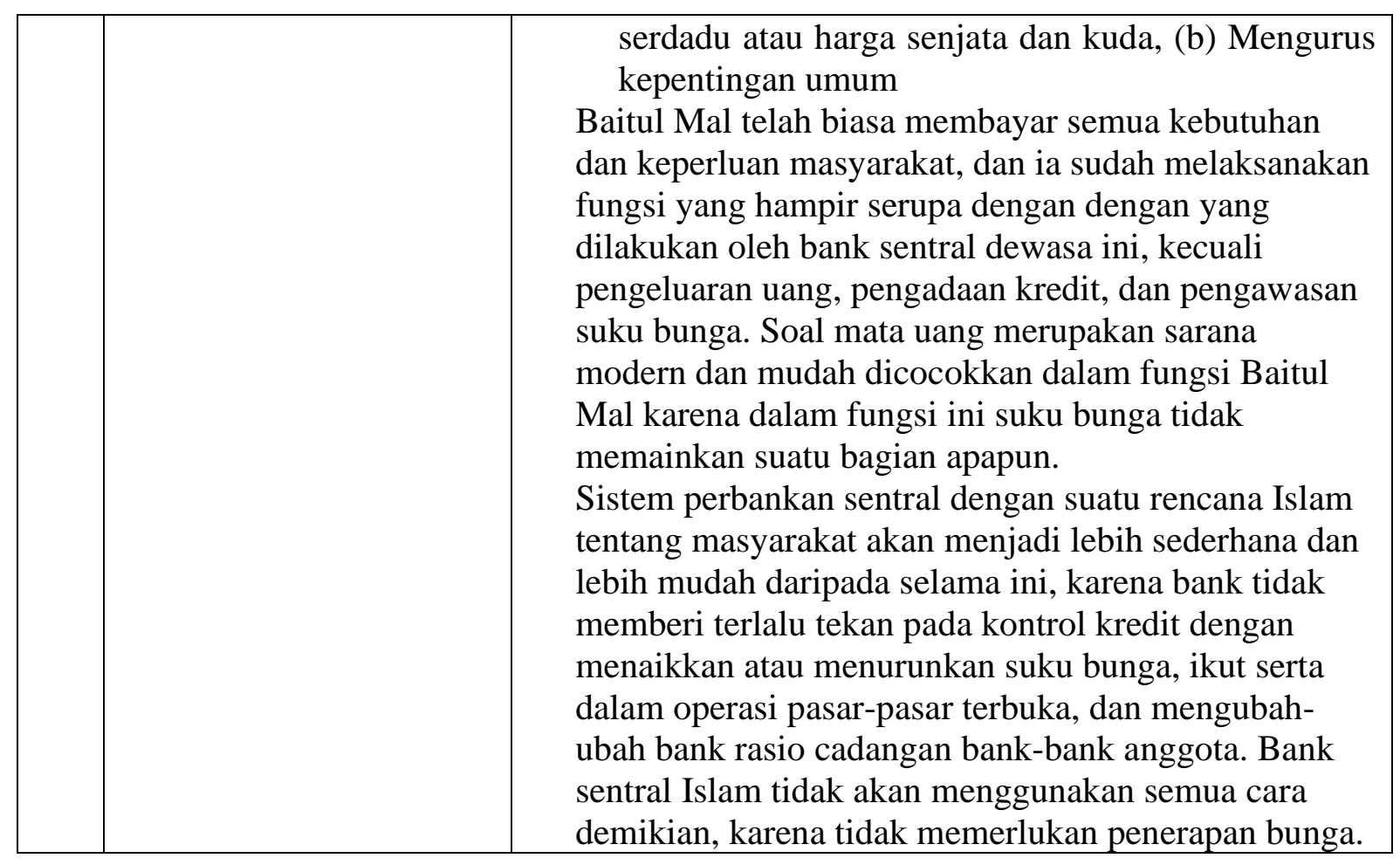

3b. Perbandingan Riba dan Perbankan M. Umer Chapra dan M. Abdul Mannan

Berikut rumus matematis union perbandingan pemikiran M. Umer Chapra dan M. Abdul Mannan dalam konsep riba dan konsep perbankan:

M. Umer Chapra =\{DR-UC, RB-UC, DNR-UC, AR-UC, DP-UC, MP-UC, MSDP$\mathrm{UC}, \mathrm{BS}-\mathrm{UC}\} \rightarrow 1$

M. Abdul Mannan $=\{$ DR-AM, RB-AM, DNR-AM, AR-AM, DP-AM,
MP-AM, MSDP$\mathrm{AM}, \mathrm{BS}-\mathrm{AM}\} \rightarrow 2$

Penulis menyimpulkan bahwa dimensi yang sama atau unsur intersection dari himpunan konsep riba dan konsep perbankan M. Umer Chapra dan M. Abdul Mannan adalah \{DR-UC, RB-UC, DNRUC, AR-UC, DP-UC, MP-UC, MSDP-UC, BS-UC, DR-AM, RB-AM, DNR-AM, ARAM, DP-AM, MP-AM, MSDP-AM, BS$\mathrm{AM}$. Berikut, penulis menyajikan Diagram Venn yang menunjukkan intersection dari himpunan-himpunan M. Umer Chapra dan M. Abdul Mannan: 


\section{Gambar 2}

\section{Diagram Venn Interseksi Dimensi M. Umer Chapra dan M. Abdul Mannan}

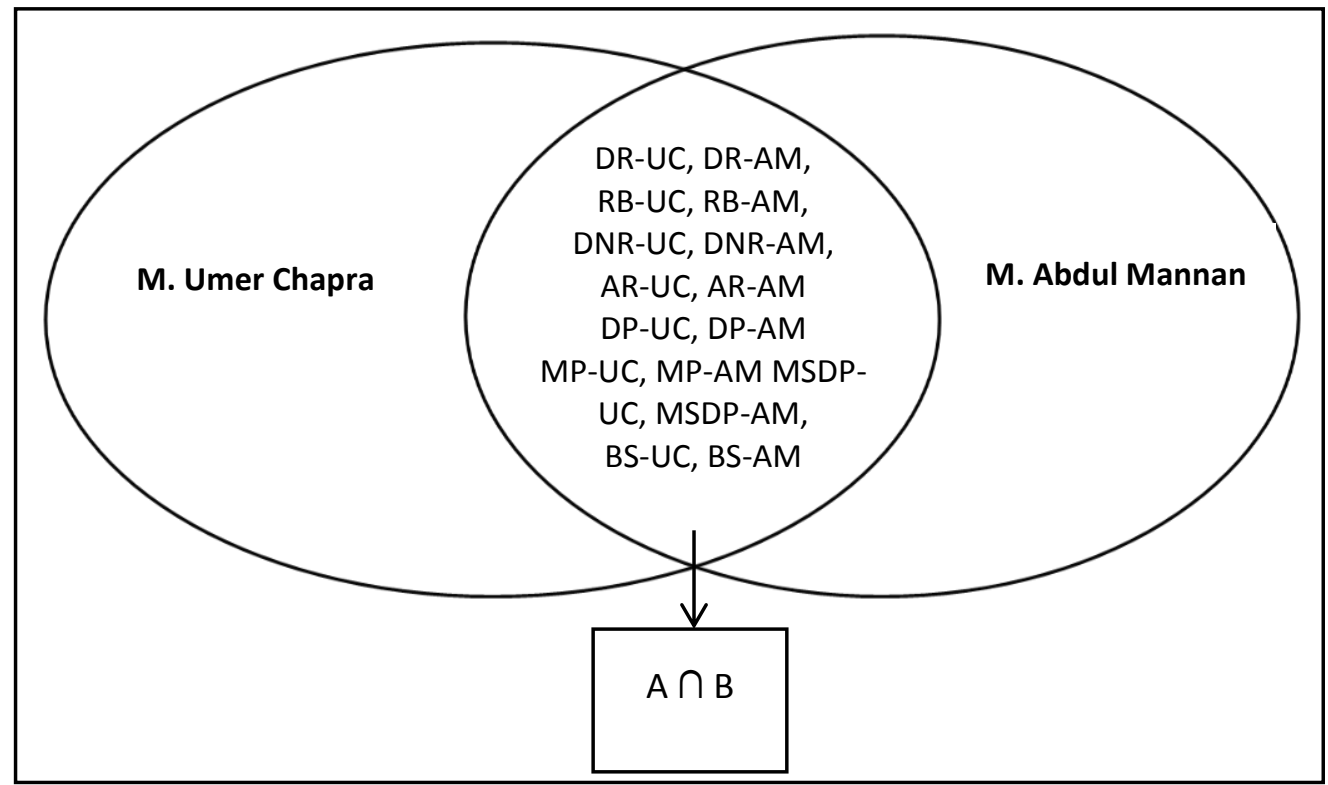

Berdasarkan gambar diagram Venn di atas, berikut penulis menjabarkan rumusan matematis yang dibuat secara rinci:

Konsep Riba M. Umer Chapra $\cap$ Konsep Riba M. Abdul Mannan $=\{$ DR-UC, DRAM, RB-UC, RB-AM, DNR-UC, DNRAM, AR-UC, AR-AM $\} \rightarrow 1$ dimana:

- M. Umer Chapra $\cap$ M. Abdul Mannan $=\{$ DR-UC, DR-AM $\}$ $\rightarrow 1 \mathrm{a}$

- M. Umer Chapra $\cap$ M. Abdul Mannan $=\{$ RB-UC, RB-AM $\}$ $\rightarrow 1 \mathrm{~b}$

- M. Umer Chapra $\cap$ M. Abdul Mannan $=\{$ DNR-UC, DNR-AM $\}$ $\rightarrow 1 \mathrm{c}$

- M. Umer Chapra $\cap$ M. Abdul Mannan $=\{$ AR-UC, AR-AM $\}$ $\rightarrow 1 \mathrm{~d}$

Konsep Perbankan M. Umer Chapra $\cap$ Konsep Perbankan M. Abdul Mannan = \{DP-UC, DP-AM, MP-UC, MP-AM, MSDP-UC, MSDP-AM, BS-UC, BS-AM $\rightarrow 2$ dimana:
- M. Umer Chapra $\cap$ M. Abdul Mannan $=\{$ DP-UC, DP-AM $\}$ $\rightarrow 2 \mathrm{a}$

- M. Umer Chapra $\cap$ M. Abdul Mannan $=\{$ MP-UC, MP-AM $\}$ $\rightarrow 2 \mathrm{~b}$

- M. Umer Chapra $\cap$ M. Abdul Mannan $=\{$ MSDP-UC, MSDP$\mathrm{AM}\} \rightarrow 2 \mathrm{c}$

- M. Umer Chapra $\cap$ M. Abdul Mannan $=\{$ BS-UC, BS-AM $\}$ $\rightarrow 2 \mathrm{~d}$

Penulis berpendapat jika demikian tokoh ilmuwan Muslim ini saling berhubungan dan cenderung serupa. Kedua tokoh ini sama-sama berpendapat bahwa riba dalam bentuk bunga dan segala manifestasinya merupakan penyebab dari krisis dan harus segera digantikan dengan sistem Islam, dan perbankan Islam harus berjalan sesuai dengan nilai-nilai Islam yang bersumber dari Al Qur'an dan Hadits.

Pemikiran M. Umer Chapra dan M. Abdul Mannan yang cenderung serupa salah satunya disebabkan karena mereka 
berasal dari negara yang sama yaitu Pakistan. Latar pendidikan mereka pun cenderung serupa, M. Umer Chapra adalah sarjana dan master bidang administrasi bisnis di Universitas Karachi, sementara M. Abdul Mannan adalah master bidang ekonomi di Rajshahi University. Mereka berdua lalu melanjutkan pendidikannya di Amerika Serikat, M. Umer Chapra mengambil gelar Ph.D. di Universitas Minnesota, sedangkan M. Abdul Mannan mengambil gelar master untuk kedua kalinya dan gelar Ph.D. di Michigan State University. Latar belakang pendidikan itulah yang mempengaruhi corak dan pendekatan dalam menyampaikan masalah ekonomi Islam terutama tentang riba dan perbankan.

M. Umer Chapra dan M. Abdul Mannan sama-sama pernah bekerja di Islamic Development Bank (IDB). Hal ini juga yang mungkin membuat Mannan dan Chapra berupaya untuk mengkolaborasikan antara pendekatan positif dan normatif dengan pendekatan ekonomi konvensional sesuai dengan latar belakang bidang keahliannya, namun juga mengkombinasikan antara ekonomi dengan nilai-nilai keislaman yang diperolehnya melalui pengalaman dan jabatan yang ia duduki dalam bidang ekonomi Islam. Oleh karena itu, dilihat dari penjelasan keduanya paling tidak setiap yang membaca akan memahami dua bidang keilmuwan secara bersamaan, yaitu ekonomi konvensional dan ilmu keislaman.

Penulis juga menemukan sedikit perbedaan dalam pemikiran M. Umer Chapra dan M. Abdul Mannan mengenai konsep riba dan perbankan ini. Perbedaan yang ditemukan oleh penulis antara lain sebagai berikut: Pertama, dalam konsep riba, Chapra lebih menjelaskan secara umum mengenai definisi riba serta makna riba di dalam Al Qur'an, Hadits, dan Fiqih. Chapra tidak secara rinci menjelaskan apa yang membedakan dan membuat kebingungan antara riba dan bunga, dan langsung menjelaskan alternatif dari kedua hal tersebut. Sedangkan Mannan menjelaskan secara rinci mengenai definisi riba, serta membedakan secara jelas mengenai persamaan antara riba dan bunga. Mannan juga menjelaskan mengapa bunga harus dibayarkan, serta menjelaskan secara rinci solusi untuk mencapai ekonomi yang terbebas dari unsur riba dan bunga.

Perbedaan kedua yang ditemukan penulis dalam pemikiran M. Umer Chapra dan M. Abdul Mannan adalah mengenai konsep perbankan. Chapra menjelaskan konsep perbankan diawali dengan persoalan-persoalan serta kritik yang dihadapai oleh bank Islam serta evaluasi untuk mengatasi persoalan dan kritik tersebut. Setelahnya Chapra lebih menjelaskan kepada definisi, perbedaan, dan mobilisasi dan investasi sumber daya pada bank komersial Islam. Chapra juga tidak menjelaskan secara rinci mengenai bank sentral Islam, Chapra hanya menjelaskan mengenai fungsi-fungsi yang harus dimiliki oleh bank sentral Islam.

Sedangkan Mannan mengawali pembahasannya dengan menjelaskan secara rinci konsep perbankan Islam, prinsipprinsip yang digunakan, serta mekanisme dari perbankan Islami itu sendiri. Mannan lebih menekankan kepada hubungan kemitraan yang dilakukan oleh bank Islam kepada para penggunanya, baik deposan maupun pengusaha. Mannan juga secara lebih rinci menjelaskan keunggulan konsep perbankan Islam serta kegiatan-kegiatan yang dapat dilakukan oleh perbankan Islam. Mannan mengawali pembahasan bank sentral dengan mengkomparasikan antara 
bank sentral modern dengan baitul mal pada masa Islam. Setelah menjelaskan mengenai baitul mal, Mannan langsung menjelaskan secara rinci mengenai pembentukan bank dunia Islam, dimulai dari faktor positif dan negatif, tujuan dan fungsi, keanggotaan dan sumber daya, serta administrasi dan manajemennya.

Dalam konteks ini dapat dilihat bahwa hanya sedikit perbedaan dari pemikiran $\mathrm{M}$. Umer Chapra dan M. Abdul Mannan mengenai konsep riba dan perbankan. Kedua tokoh tersebut memiliki porsi kelebihan dan kekurangannya masingmasing. Setelah ditelaah secara deskriptif di atas dapat diterangkan bahwa M. Umer Chapra lebih menjelaskan secara umum mengenai konsep riba dan perbankan, sedangkan M. Abdul Mannan menjelaskannya secara lebih rinci.

\section{E. KESIMPULAN}

Hasil dari analisis himpunan dapat dikatakan bahwa dimensi \{DR-UC, RBUC, DNR-UC, AR-UC, DP-UC, MP-UC, MSDP-UC, BS-UC, DR-AM, RB-AM, DNR-AM, AR-AM, DP-AM, MP-AM, MSDP-AM, BS-AM\} milik M. Umer Chapra dan M. Abdul Mannan digolongkan ke dalam dimensi yang interseksi (sama atau sejenis). Pemikiran kedua tokoh ekonomi Islam ini saling berhubungan satu sama lain dan cenderung serupa. Kedua tokoh sepakat untuk mengintegrasikan nilai-nilai Islam yang bersumber dari $\mathrm{Al}$ Qur'an dan Hadits ke dalam aktivitas ekonomi.

Pemikiran M. Umer Chapra dan M. Abdul Mannan yang cenderung serupa salah satunya disebabkan karena mereka berasal dari negara yang sama yaitu Pakistan. Latar pendidikan mereka pun cenderung serupa, M. Umer Chapra adalah sarjana dan master bidang administrasi bisnis di Universitas Karachi, sementara M. Abdul Mannan adalah master bidang ekonomi di Rajshahi University. Mereka berdua lalu melanjutkan pendidikannya di Amerika Serikat, M. Umer Chapra mengambil gelar Ph.D. di Universitas Minnesota, sedangkan M. Abdul Mannan mengambil gelar master untuk kedua kalinya dan gelar Ph.D. di Michigan State University. Kedua tokoh ini pun sama-sama pernah bekerja di Islamic Development Bank (IDB).

Dalam konteks ini dapat dilihat bahwa hanya sedikit perbedaan dari pemikiran M. Umer Chapra dan M. Abdul Mannan mengenai konsep riba dan perbankan. Kedua tokoh tersebut memiliki porsi kelebihan dan kekurangannya masingmasing. Setelah ditelaah secara deskriptif di atas dapat diterangkan bahwa M. Umer Chapra lebih menjelaskan secara umum mengenai konsep riba dan perbankan, sedangkan M. Abdul Mannan menjelaskannya secara lebih rinci.

\section{F. SARAN}

Berdasarkan kesimpulan dan keterbatasan penelitian yang dialami penulis, penelitian ini menghasilkan beberapa saran yang dapat diberikan, yaitu:

1. Melengkapi data penelitian dan mempermudah akses data berupa literatur-literatur ekonomi Islam yang terkait pemikiran para tokoh ekonomi Islam.

2. Memperluas wilayah penelitian dalam hal lain seperti bidang moneter, keuangan publik, konsumsi, dan produksi. 


\section{G. UCAPAN TERIMA KASIH}

Terima kasih kami haturkan kepada Bapak Darwanto, S.E., M.Si., M.Sy., selaku Ketua Program Studi Ekonomi Islam Fakultas Ekonomika dan Bisnis Universitas Diponegoro yang telah memfasilitasi riset dan memberikan pendampingan dalam pelaksanaan penelitian dan penulisan artikel.

\section{DAFTAR PUSTAKA}

Ab. Ghani, Ab. Mumin dan Fadillah Mansor. (2006). Dinamisme Kewangan Islam di Malaysia". Kuala Lumpur: Universiti Malaya.

Abdullah, Boedi. (2010). Peradaban Pemikiran Ekonomi Islam. Bandung: Pustaka Setia.

Abustan. (2009). Analisa Perbandingan Kinerja Keuangan Perbankan Syariah dengan Perbankan Konvensional". Depok: Fakultas Ekonomi Universitas Gunadarma.

Al Ghazali, Abu Hamid. (1991). Al Mustahfa min Ilmi Al Ushul. Madinah: Universitas Islam Madinah.

Al Kaaf, Abdullah Zakiy. (2002). Ekonomi dalam Perspektif Islam. Bandung: CV Pustaka Setia.

Al Mawardi, Ali bin Habib. (1982). An Nukat wa Al Uyun Tafsir Al Mawardi. Kuwait: Wizarat Al Auqaf wa As Syu'un Al Islamiyah.

Amartiwi, Aulia. (2018). "Perbandingan Pemikiran Umer Chapra dan Yusuf Qardhawi Tentang Sistem Ekonomi Islam". Semarang: Universitas Diponegoro.

Anas, IF. (2008). "Analisis Komparatif Pemikiran Muhammad Abdul Manan Dan Monzer Kahf Dalam Konsep Konsumsi Islam.” Jurnal UIN Syarif Hidayatullah.

Antonio, Muhammad Syafi'i. (2006). Dasar-Dasar Manajemen Bank Syariah. Jakarta: Pustaka Alfabeta

Antonio, Muhammad Syafi'i. (2017). Bank Syariah dari Teori ke Praktik. Depok:
Gema Insani

Ar Razi, Muhammad Fakhruddin. (1981). Tafsir Al-Fakhr Ar-Razi Asy-Syahir bi Tafsir Al Kabir wa Mafatih Al Ghaib. Beirut: Dar el Fikr.

Aravik, Havis. (2017). Sejarah Pemikiran Ekonomi Islam Kontemporer. Depok: Kencana.

Arifin, Zainul. (1999). Memahami Bank Syariah. Jakarta: Alvabet

Ascarya. (2007). Akad dan Produk Bank Syariah. Jakarta: RajaGrafindo Persada

Athiyyah, Muhyi al Din. (1992). Al Kasysyaf Al Iqtishadi Li Ayat Al Qur'an Al Karim. Riyadh: Al Dar al Ilmiyah Lil Kitab al Islami.

Aziz, Fathul Aminuddin. (2014). Riba dalam Perspektif Hukum dan Fiqih Manajemen". el-JIZYA Vol. II No. 1.

Bakar, Abu. (2018). "Riba dalam Muamalah (Studi Terhadap HadisHadis Riba)". Yogyakarta: UIN Sunan Kalijaga.

Chair, Wasilul. (2014). Riba dalam Perspektif Islam dan Sejarah". Iqtishadia Vol. 1 No. 1.

Chamid, Nur. (2010). Jejak Langkah Sejarah Pemikiran Ekonomi Islam. Yogyakarta: Pustaka Pelajar.

Chapra, M. Umer. (2000). Islam dan Tantangan Ekonomi. cet 1 . ed. Sholihat. Jakarta: Gema Insani Pers.

Chapra, M. Umer. (2000). The Future of Economics (An Islamic Perspective). United Kingdom: The Islamic Foundation.

Chapra, M. Umer. (2018). Masa Depan Ilmu Ekononomi: Sebuah Tinjauan Islam. Terjemahan: Ikhwan Abidin Basri. Sukoharjo: Aqwam.

Chapra, M. Umer. (2018). Islam dan Tantangan Ekonomi. Terjemahan: Ikhwan Abidin Basri. Sukoharjo: Aqwam.

Chapra, M. Umer. (2018). Sistem Moneter Islam,. Terjemahan: Ikhwan Abidin Basri. Sukoharjo: Aqwam.

Chapra, M. Umer. (2018). Visi Islam dalam Pembangunan Ekonomi Menurut Maqosid Asy-Syariah. Terjemahan: 
Ikhwan Abidin Basri. Sukoharjo: Aqwam.

Chapra, M. Umer. (2018). Reformasi Ekonomi Sebuah Solusi Perspektif Islam. Terjemahan: Ikhwan Abidin Basri. Sukoharjo: Aqwam.

Chapra, M. Umer. (2018). Islam dan Pembangunan Ekonomi. Terjemahan: Ikhwan Abidin Basri. Sukoharjo: Aqwam.

El Diwani, Tarek. (2003). The Problem with Interest. Jakarta: Akbar Media Eka Sarana.

Fajar, Riza Yulista. (2009). Riba dan Bunga Bank dalam Pandangan Muhammad Syafi'i Antonio". Yogyakarta: Universitas Islam Negeri Sunan Kalijaga.

Fogel, Frank dan Samuel Hayes. (2007). Hukum Keuangan Islam: Konsep, Teori, dan Praktik. Bandung: Nusamedia.

Ghofur, Abdul. (2016). Konsep Riba dalam Al-Qur'an". Economica Vol. VII Edisi 1.

Hakim, M. Arif. (2015). "Peran Pemerintah Dalam Mengawasi Mekanisme Pasar Dalam Perspektif Islam. Iqtishadia 8(1): 19-40.

Haneef, Mohamed Aslam. (2010). Pemikiran Ekonomi Islam Kontemporer. 1st ed. Jakarta: Rajawali Pers.

Harahap, Nursapia. (2014). Penelitian Kepustakaan." Jurnal Iqra' 08(01): 68-73.

Hasan, Nurul Ichsan. (2014). Perbankan Syariah: Sebuah Pengantar. Jakarta: GP Press Group

Hasibuan, Malayu S.P. (2001). DasarDasar Perbankan. Jakarta: PT Bumi Aksara.

Hoed, Benny H. (2008). Semiotik Dan Dinamika Sosial Budaya $\square$ : UI Depok. Depok.

Hosein, Imran N. (1997). Larangan Riba dalam Al Qur'an dan Sunnah. Malaysia: Ummavision Sdn. Bhd.

Ikhwan, Wahyu. (2010). "Riba dan Bunga Bank Perspektif Moh. Hatta".
Yogyakarta: UIN Sunan Kalijaga.

Iqbal, Zamir dan Abbas Mirakhor. (2008).

Pengantar Keuangan Islam. Jakarta:

Kencana.

Izziyana, Wafda Vivid. (2017). "Mekanisme Prinsip-Prinsip Syariah dalam Operasional Bank Syariah". Jurnal Law and Justice Vol. 2 No. 1.

Jaelani, Abdul Qadir. (2012). Bunga Bank dalam Perspektif Sosio-Ekonomi dan Ushul Fiqh (Studi atas Pemikiran M. Umer Chapra)". Asas Jurnal Vol. 4 No. 2.

Kalsum, Ummi. (2014). Riba dan Bunga Bank dalam Islam”. Jurnal Al-Adl Vol. 7 No. 2.

Karim, Adiwarman Azhar. (2008). Sejarah Pemikiran Ekonomi Islam. Jakarta: RajaGrafindo Persada.

Karim, Adiwarman Azhar dan Oni Sahroni. (2015). Riba, Gharar, dan KaidahKaidah Ekonomi Syariah: Analisis Fikih \& Ekonomi. Jakarta: PT RajaGrafindo Persada.

Kasmir. (2011). Bank dan Lembaga Keuangan Lainnya. Jakarta: PT RajaGrafindo Persada.

Kholila, Siti. (2018). Pengaruh Motivasi Menghindari Riba dan Pengetahuan Produk Perbankan Syariah Terhadap Keputusan Menjadi Nasabah di Bank Muamalat KC Surabaya-Mas Mansyur". Surabaya: UIN Sunan Ampel.

Mannan, M. Abdul. (1995). Teori dan Praktek Ekonomi Islam. Terjemahan: M. Nastangin. Jakarta: Dana Bakti Prima Yasa

Marwini. (2017). Kontroversi Riba dalam Perbankan Konvensional dan Dampaknya Terhadap Perekonomian. Az-Zarqa' Vol. 9 No. 1.

Mubyarto. (2007). Membangun Sistem Ekonomi. Yogyakarta: BPFE

Muhajir. (2013). Pendekatan Komparatif Dalam Studi Islam. 2(2): 1-10.

Muhammad. (2004). Ekonomi Mikro dalam Perspektif Islam. Yogyakarta: BPFE.

Muhammad. (2016). Bank Syariah: Analisis Kekuatan, Kelemahan, 
Peluang, dan Ancaman. Yogyakarta: Exsonisia.

Mustofa, Agus. (2018). Riba Versus Sedekah. Surabaya: Padma Press

Nafik, Muhammad. (2009). Benarkah Bunga Haram?. Surabaya: Amanah Pustaka.

Nairozi. M Sabiq. (2013). "Pandangan M. Abdul Mannan Tentang Sistem Ekonomi Islam Berdasarkan Konsep Persaudaraan." Semarang: IAIN Walisongo.

Naqvi, Syed Nawab Haider. (2003). Menggagas Ilmu Ekonomi Islam. Yogyakarta: Pustaka Pelajar.

Nasution, Mustafa Edwin. (2007). Pengenalan Ekslusif Ekonomi Islam. Jakarta: Kencana.

Nurdin, Muh. Syarif. (2016). Perbankan Syariah (Studi Perbandingan Pandangan Antara Nejatullah Siddiqi dan Afzalur Rahman). Makassar: UIN Alauddin.

Nurhadi. (2017). Bunga Bank antara Halal dan Haram. Jurnal Nur El-Islam Volume 4 Nomor 2.

Poerwadarminta. (1999). Kamus Umum Bahasa Indonesia. Jakarta: Balai Pustaka.

Priono, Djaka Heru. (2006). Ekonomi Islam Baqir Sadr Dan Monzer Kahf: Sebuah Studi Komparatif'. Jakarta: UIN Syarif Hidayatullah.

Qudamah, Ibnu. (1997). Al Mughni. Riyadh: Dar'alim Al Kutub.

Rahardjo, M. Dawam. (1999). Islam dan Transformasi Sosial Ekonomi. Jakarta: LSAF

Rahim, Abdul. (2015). Konsep Bunga dan Prinsip Ekonomi Islam dalam Perbankan Syariah. Human Falah Vol. 2.

Rahmawaty, Anita. (2013). Riba dalam Perspektif Keuangan Islam”. Jurnal Hukum Islam STAIN Kudus.

Rasyidi, M. (1976). Hukum Islam dan Pelaksanaannya dalam Sejarah. Jakarta: Bulan Bintang.

Rivai, Veithzal, et.al. (2007). Bank and Financial Institution Management
Conventional and Sharia System. Jakarta: RajaGrafindo Persada

Saeed, Abdullah. (2008). Bank Islam dan Bunga: Studi Kritis Larangan Riba dan Interpretasi Kontemporer. Terjemahan: Muhammad Ufuqul Mubin et.al. Yogyakarta: Pustaka Pelajar.

Salim, Agus. (2005). "Pandangan Neomodernisme Islam Tentang Riba dan Bunga Bank (Studi Atas Pemikiran Fazlur Rahman)". Yogyakarta: UIN Sunan Kalijaga.

Sanrego, Yulizar D. dan Ismail. (2015). Falsafah Ekonomi Islam. Jakarta: CV Karya Abadi.

Shihab, M. Quraish. 2008. Tafsir alMisbah. Jakarta: Lentera Hati.

Sodiq, Amirus. (2015). Konsep Kesejahteraan dalam Islam". Equilibrium Vol. 3 No. 2.

Soemitro, Warkum. (2004). Asas-Asas Perbankan Islam dan LembagaLembaga Terkait (Takaful dan Pasar Modal Syariah) di Indonesia. Jakarta: PT RajaGrafindo Persada

Sukirno, Sadono. (1997). Pengantar Teori Makro Ekonomi Edisi Kedua. Jakarta: PT RajaGrafindo Persada

Sura'i, Abu. (1993). Bunga Bank dalam Islam. Surabaya: Al Ikhlas.

Suryani. (2012). "Sistem Perbankan Islam di Indonesia: Sejarah dan Prospek Pengembangan". Jurnal Muqtasid Vol. 3 No.1.

Suwandi dan Basrowi. (2008). Memahami Penelitian Kualitatif. Jakarta: Rineka Cipta.

Syarif, Mujar Ibnu. (2011). "Konsep Riba dalam AlQuran dan Literatur Fikih". Al-Iqtishad Vol. III No. 2.

Tho'in, Muhammad. (2016). Larangan Riba dalam Teks dan Konteks (Studi atas Hadits Riwayat Muslim Tentang Pelaknatan Riba)". Jurnal Ilmiah Ekonomi Islam Vol. 02 No. 02.

Tim Pengembangan Perbankan Syariah Institut Bankir Indonesia. 2011. Bank Syariah: Konsep, Produk, dan 
Implementasi Operasional. Jakarta: Djambatan.

Ulum, Fahrur. (2013). Excutive Summary Dinamika Konstruksi Sistem Ekonomi Islam (Studi Komparasi Pola Pemikiran Beberapa Tokoh Ekonomi Islam Kontemporer)." : 0-25.

Widyaningsih, et.al. (2015). Bank dan Asuransi Islam di Indonesia. Jakarta: Kencana.

Wijaya, Dody Adi. (2017). “Analisis Peran Perbankan Syariah dalam Mengimplementasikan Keuangan Inklusif di Indonesia". Yogyakarta: UIN Sunan Kalijaga.

Wilardjo, Setia Budhi. (2005). Pengertian, Peran dan Perkembangan Bank Syari'ah di Indonesia". Jurnal Unimus Vol. 2 No.1.

Yuliadi, Imamudin. (2001. Ekonomi Islam: Sebuah Pengantar. Yogyakarta: Lembaga Pengkajian dan Pengamalan Islam (LPPI).

Zuhaili, Wahbah. (1985). Al Fiqh al Islami wa Adillatuhu. Damaskus: Dar al Fikr. 